\title{
O Grafite em Fortaleza
}

Resumo: $\mathrm{O}$ artigo aborda a produção do grafite e as dinâmicas de sua legitimação durante a gestão municipal conhecida como Fortaleza Bela (2004-2012). Face às recentes transformações urbanas, discutimos de que modo o grafite dialoga com as políticas culturais voltadas para a espetacularização da cidade. A prática do grafite configura-se a partir de dois diferentes tipos de ação: uma defende maior adesão às demandas populares; a outra, insere essa prática nos limites entre a rua e o mundo artístico.

Palavras-chave: Grafite; Espetacularização; Políticas Públicas; Cultura; Fortaleza.

\section{Kadma Marques Rodrigues}

Professora e coordenadora do Mestrado Acadêmico em Políticas Públicas e Sociedade / MAPPS - UECE. kadmamarques@uece.br

\section{$\overline{\text { Nicole Sousa Bessa }}$}

Bacharel em Ciências Sociais pela UECE.

nicole_bessaa@hotmail.com

\author{
Kadma Marques Rodrigues \\ Nicole Sousa Bessa
}

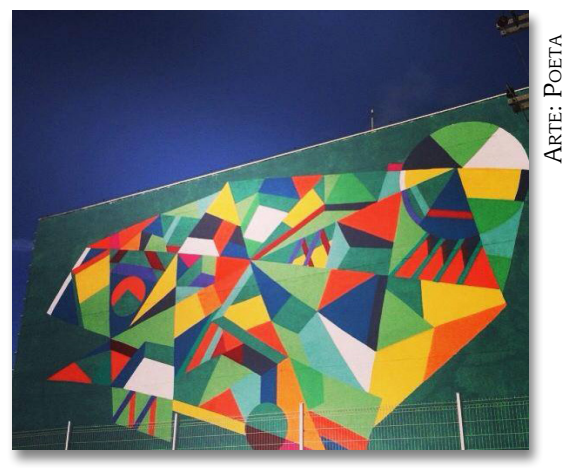

\section{Graffiti in Fortaleza}

Abstract: The article approaches the production of graffiti and the dynamics of its legitimation during the years of the municipal management known as Fortaleza Bela (2004-2012). In the light of recent urban transformations, we discuss how graffiti dialogues with cultural policies aimed at spectacularizing the city. The practice of graffiti is shaped by two different kind of actions: one advocate a greater adherence to popular demands; the other inserts this practice in the boundaries between the street and the artistic world.

Keywords: Graffiti; Spectacularization; Public Policies; Culture; Fortaleza.

$\overline{\text { RECEBIDO EM } 15-03-2015}$

$\overline{\text { APROVADO EM } 21-05-2015}$ 


\section{INTRODUÇÃO}

De julho de 2009 a janeiro de 2010, a Fundação Cartier para a Arte Contemporânea, apresentou em Paris a exposição Né dans la rue - Graffiti, em uma manifestação inconteste de consagração desta produção imagética no domínio das artes plásticas.

Reunindo "artistas do grafite" da Europa e das Américas, tal exposição colocou em evidência a extraordinária vitalidade de um movimento que emergiu das ruas de Nova Iorque, no início dos anos 1970. No contexto da década de 1980, a trajetória exemplar do "artista maldito" Jean-Michel Basquiat (1960-1988)1 contribuiu para a conversão do grafite em um fenômeno plástico mundial.

Solidamente ancorada na paisagem urbana ${ }^{2}$, a prática do grafite representa um desafio à gestão da cidade que se faz por meio da arte e da cultura. No contexto global da chamada revitalização de espaços degradados, o grafite se faz presença constante, convertido em marca da tensão entre a afirmação de diferenciações locais e a face homogeneizante do movimento de mundialização da cultura.

Acrescente-se a isso que a beleza da cidade agenciada pela arquitetura e urbanismo faz muitas vezes convergir o patrimônio edificado tradicional e as formas de arquitetura ditas ecléticas ou pós-modernas. Frente a tais agentes, investidos pelos poderes públicos da tarefa de conformar a paisagem urbana, o grafite continua representando uma manifestação artístico-cultural não completamente controlada, pois se apropria e transforma lugares marcados seja pelo transbordamento de apelos publicitários, seja pelo já citado estado de degradação.

Ora, o aparente consenso criado pelo urbanismo em torno da dimensão estetizante e da espetacularização das cidades contemporâneas aponta que, na conversão dos espaços urbanos em cenários para eventos turísticos, há uma relação inversamente

1 Primeiramente, Basquiat ganhou popularidade por seus grafites em metrôs e prédios abandonados de Manhatan/estado de Nova Iorque, para posteriormente ser consagrado como artista, ícone do neo-expressionismo norte-americano.

2 Para compreender o percurso histórico feito pela noção de paisagem, de sua acepção ligada à natureza àquela que assume o sentido de paisagem urbana ver Cauquelin, Anne. L'invention du paysage. 
proporcional entre espetáculo e participação popular como elemento definidor de usos do espaço público (JACQUES, 2004).

Apesar disso, em Fortaleza, é possível notar que houve na última década uma expansão sem precedentes do movimento do grafite. De fato, a difusão de tal prática tem se dado não só pelo aumento quantitativo de grupos que intervêm nas cidades, mas também pela atração que tem exercido sobre "talentos" saídos da rua e de outros regimes de produção imagética. Assim, a publicidade, a arte, a moda e os poderes públicos e privados têm mantido intercâmbios com o grafite, entendido como um recurso comunicacional alternativo capaz de renovar as experiências visuais já desenvolvidas por estes meios.

Ao iniciar esta pesquisa, ficaram imediatamente claros os obstáculos que se interporiam à apreensão do universo configurado pela prática do grafite em Fortaleza: portadores de uma história fragilmente construída, os "grafiteiros" da capital cearense pautam-se por diversas lógicas na elaboração de suas produções, bem como, caracterizam-se pelo uso diferenciado que fazem de suportes e temáticas.

Desse modo, esse campo empírico caracteriza uma realidade complexa, marcada por relações de concorrência entre segmentos que se afirmam como "marginais" e outros que se encontram em vias de reconhecimento público e institucional. Esta configuração evidencia tanto elementos que são homólogos a outros campos de ação social (a disputa pela hegemonia), quanto àquilo que particulariza este fenômeno (os valores que norteiam essa disputa).

Assim, se inicialmente o desafio imposto por tal campo empírico implica a apreensão do processo de criação do grafite em Fortaleza, isto exige a adoção da etnografia como procedimento metodológico, mediante escolha de um grupo representativo, tomado como caso particular do possível (BOURDIEU, 1989).

Porém, para além da manifestação do fenômeno, faz-se necessário ainda problematizar a ligação da prática do grafite com cinco elementos: 1) a beleza na cidade; 2) a trajetória social do produtor de grafites; 3) sua interpretação quanto ao papel social e a estratégias de reconhecimento; 4) lógica empregada para a escolha dos lugares e a utilização de técnicas do grafite e 5) categorização de 
sua própria produção quanto a temas, técnicas e referências de outros grupos.

Inicialmente, os grupos que se constituíram como objeto de trabalho etnográfico foram o Grafiticidade e o Acidum. Neste artigo, a partir das observações preliminarmente registradas no trabalho de campo, desenvolvido desde janeiro de 2010, é possível apontar a seguir algumas considerações acerca da dinâmica social mobilizada pela prática do grafite e as relações que podem ser estabelecidas entre esta e a gestão municipal anunciada pelo programa Fortaleza Bela (2004-2008; 2008-2012).

\section{FORTALEZA BELA - EM QUE CONSISTE A BELEZA DA CIDADE?}

Indagado sobre a relação entre espaço urbano e o sentido amplo e integrativo do conceito de beleza, Paulo Roberto Pinto ${ }^{3}$ afirma que as cidades, a exemplo de Fortaleza, são concebidas pelo poder público local como uma reunião de seres humanos e aspectos físicos, envolvidos por uma acepção global de beleza. Para ele, cada cidade revela sua dimensão estética por meio de peculiaridades específicas não só de aspectos naturais, típicos de cada região, mas também do povo, entendido como um conglomerado de pessoas que portam aspectos singulares, os quais se configuram cotidianamente nas relações e no comportamento dos habitantes de um território. Por isso, a beleza da cidade pode ser desfigurada em face de condições vivenciais inadequadas para as pessoas que nela habitam ou a visitam.

O combate a esta possível desfiguração da beleza da cidade orientou a formulação do lema de campanha que levou Luiziane Lins (representante do Partido dos Trabalhadores - PT, em Fortaleza) a assumir a Prefeitura da capital cearense, por dois

3 Paulo Roberto Coelho Pinto é Professor Catedrático do Curso de Economia da Universidade Federal do Ceará (UFC) e Ex-Secretário de Planejamento do Município de Fortaleza, de 1975 a 1979. (Fonte: entrevista concedida a Luciara Silveira de Aragão e Frota para a Cordis - Revista Eletrônica de História Social da Cidade - em 07/10/2008). 
mandatos consecutivos (2004-2008; 2008-2012) $)^{4}$. Assim, com o programa Fortaleza Bela Quero Te Ver, a Prefeitura assumiu o compromisso de zelar pela cidade a partir da requalificação do espaço urbano, com a participação da Comunidade 5 .

Neste contexto, tal requalificação refere-se especificamente à intervenção do poder público para recuperação/manutenção de lugares que beneficiam a coletividade tais como praças, jardins, parques, canteiros das vias urbanas, áreas verdes e demais espaços públicos da cidade ${ }^{6}$, mas também, a limpeza de canais, rios, riachos e lagoas próximas a áreas habitadas por populações em situação de risco ${ }^{7}$.

Em Fortaleza, esse processo de revitalização urbana manifesta localmente uma tendência global. Nesse sentido, a cidade tem passado de forma mais evidente, nas duas últimas administrações municipais, por uma série de intervenções públicas que enfatizam não apenas investimentos nesses lugares, mas também na cultura como elemento que dinamiza a vida urbana. Jacques (2004, p. 24) afirma que

Neste novo processo urbano do mundo globalizado a cultura vem se destacando como estratégia principal da revitalização urbana, pois esses particularismos culturais geram slogans que podem marcar um lugar singular no competitivo mercado internacional, onde cidades do mundo todo disputam turistas e investimentos estrangeiros.

Porém, dentre os particularismos assumidos em cada realidade específica, na capital cearense, o Decreto Municipal ${ }^{8}$ que instituiu a Comissão de Trabalho encarregada da execução do Programa

4 Souza (2007) lembra dois exemplos semelhantes, em termos de administrações municipais no Brasil, ambos na gestão 2000-2004, precedendo, portanto, a experiência de Fortaleza. Porém, aqueles trouxeram pichadores e grafiteiros à cena política para discutir a utilização dos espaços públicos da cidade. São eles: a Operação Belezura, da Prefeitura de São Paulo, sob o governo de Marta Suplicy (PT); e o Projeto Guernica, organizado pelo Prefeito de Belo Horizonte, Célio de Castro (PSB-PT).

5 Fonte: disponível em: $<$ http://www.fortaleza.ce.gov.br/index.php?option=com content\&task=view\& id=14653\&Itemi $>$. Acesso em: 20 dez. 2010.

6 Idem.

7 Idem ibdem.

8 Decreto $\mathrm{n}^{\circ} 12.568$ de 24 de agosto de 2009. Diário Oficial do Município, ano LVII, n. 14.131, 26 ago. 2009. 
Fortaleza Bela, acrescentava como parte das ações delineadas para requalificação dos espaços públicos, o combate à poluição visual e sonora.

Embora tal medida aponte os contornos significativos que este elemento pode ter no processo de desqualificação da "beleza" dessa cidade, ela não discrimina o que o poder público compreende por "poluição visual", e menos ainda quais seriam suas formas de manifestação. Assim, é preciso considerar que:

Apesar dessa espetacularização generalizada, as cidades
brasileiras, de uma forma geral, talvez até por sua informa-
lidade, ainda conseguem manter algum tipo de diversidade,
de multiplicidade no espaço urbano. Mesmo estando sujei-
tos ao rolo compressor homogenisador [sic] da cidade-es-
petáculo, atores sociais urbanos ainda conseguem reverter
o processo ao se apropriar de espaços públicos, para habita-
ção ou encontros ou eventos dos mais variados (JACQUES,
2004, p. 27).

Frente a este contexto, as imagens elaboradas pela prática do grafite manifestam uma dentre as possíveis formas de apropriação dos espaços públicos por atores sociais urbanos, embora muitas vezes tenham sido associadas a modos "indesejáveis" de produção visual, a exemplo da pichação. Porém, mesmo havendo um intenso intercâmbio entre agentes de ambas as práticas, o grafite exemplifica melhor a condição ambígua que oscila entre a atribuição de "poluição visual" pelo senso comum e a celebração como forma artística feita por outros setores.

Ao que parece, no fundamento do grafite permanece a relação de estranhamento e o desejo pela reconfiguração de territórios, ambos mediados por uma produção que busca um forte impacto visual. No entanto, como apropriação de um movimento urbano "revolucionário" e "rebelde", uma política cultural urbana de grafite pintado poderia alterar esta prática em seu cerne? Ou seja: sua institucionalização e legitimação pelo poder público provocaria a erradicação desta como uma prática subversiva? Ora, afirma Guerrero (2014):

O espaço urbano e o espaço público são um reflexo da sociedade, aquilo que representa o seu caráter, suas necessidades, seus valores e seus gostos. Neste, dentre as muitas expressões murais, esculturas, equipamentos culturais 
e ritmos intensos, os grafites constituem performances ao vivo de arte urbana.

No contexto da enorme diversidade visual revelada tanto pela esfera material como por ativos intangíveis que configuram concretamente ruas, avenidas, praças, parques e jardins, o grafite passa a disputar espaço com outras expressões culturais. Do mesmo modo, ele se encontra presente em galerias comerciais, salas de edifícios, estações ferroviárias, clubes e espaços públicos, onde rivaliza com a lógica comercial que atravessa toda a condição urbana.

Assim, retomando o já citado programa Fortaleza Bela, é preciso considerar ainda que ele traça convergências entre o processo de requalificação urbana e os ideais democráticos apregoados por aquela gestão municipal na forma de uma efetiva participação da Comunidade. Afinal, nesse contexto, o sentido conferido à revitalização urbana, apontaria antes a idéia de vitalidade, como vida decorrente da presença de um "público" e de atividades diversificadas, do que o viés econômico. Ora, tal concepção

só poderá se realizar de forma não espetacular quando ocorrer uma apropriação popular e participativa do espaço público. O que evidentemente não pode ser completamente planejado, predeterminado ou formalizado (JACQUES, 2004, p. 27).

Neste contexto, a prática do grafite revela a exigência de flexibilidade no planejamento urbano como uma dimensão muito particular da gestão da cidade pela via da cultura e da arte. Ela enfatiza, à maneira do urbanismo situacionista, uma compreensão do meio urbano como terreno de ação, de produção de novas formas de intervenção e de luta contra a monotonia da vida cotidiana moderna (JACQUES, 2004, p. 26). 


\section{GRAFITANDO EM UM CAMPO DE TENSÕES}

Se, como afirma Bourdieu (1989), "O real é relacional", o horizonte de compreensão forjado neste artigo alarga-se consideravelmente quando as produções do Grafiticidade e do grupo Acidum são consideradas por representarem pólos aparentemente opostos em um "campo de tensões". Tais pólos são perpassados pelas influências e intercâmbios com outros coletivos do grafite local, os quais encarnam diversas concepções de beleza ligada ao espaço público.

As referências a tais grupos evidenciam filiações simbólicas desta prática, a qual se concretiza em vertentes que influenciaram a configuração do grafite em Fortaleza tal como o conhecemos hoje. Inicialmente é possível apontar ao menos duas dentre tais filiações: a primeira emerge em consonância com a cultura Hip Hop, no âmbito da qual o grafite é concebido como uma "manifestação gráfica plástica" utilizada pelos integrantes desta para tratar problemas sociais; a segunda vertente conforma-se por sua relação com o domínio das artes plásticas, influenciada especificamente pela precedência do movimento artístico denominado Muralismo, o qual propunha uma arte acessível à maioria da população, usando para isso os muros e paredes de edifícios públicos. (DIÓGENES, 2008). Esta, porém, não é uma tendência apenas local. Sobre o grafite no Rio de Janeiro, Souza (2007, p. 20-21) afirma:

Hoje em dia se chega a estabelecer um racha entre o graffiti de matriz nas artes plásticas, relacionado ao muralismo e à pop art, que herdou desta última recursos como máscaras e moldes vazados (estêncil), e o estilo de graffiti relacionado ao movimento hip-hop (a chamada estética novaiorquina), cuja expansão se deu durante a década de 1990 e que materializa imagens referentes às temáticas das letras dos raps: desigualdade social e violência policial dão a tônica.

No Brasil, o surgimento e a expansão do grafite estiveram ligados majoritariamente ao movimento Hip Hop, e Fortaleza não foi exceção à regra. Contudo, contemporaneamente na capital cearense, o grafite não se restringe mais apenas à influência deste movimento. Ao contrário, estudantes de artes plásticas, 
ex-pichadores ${ }^{9}$, integrantes de ONGs, de instituições públicas e outros agentes sociais se apropriam cada vez mais desta prática, imprimindo-lhe novos sentidos, temáticas e técnicas.

Neste sentido, a trajetória realizada pelo grupo Grafiticidade aponta um exemplo ilustrativo. Este coletivo formou-se em 2002, quando seus integrantes tiveram um contato inicial a partir de atividades conjuntas desenvolvidas no âmbito de um projeto de arte e educação ${ }^{10}$, promovido pela Prefeitura de Fortaleza.

Figura 1 - Imagem do Grafiticidade

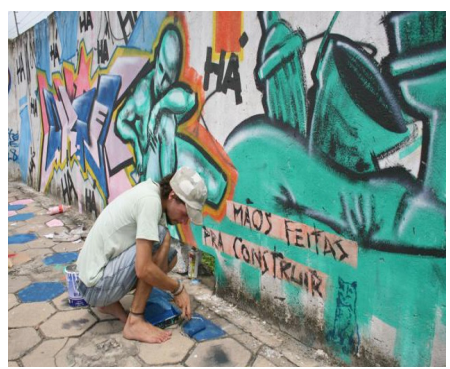

Fonte: disponível em: <http://www.overmundo.com.br/agenda/ exposicao-coletivano-ccbnb-apresenta-grafite-como-linguagem-artistica\#-agenda-6324>.

No referido projeto, o grafite era uma das formas artísticas ensinadas. Desde então, o grupo, além de grafitar especialmente nos bairros Benfica e Centro, ministra oficinas sobre a arte do grafite.

Conforme entrevista com um de seus membros, esta prática teria começado a surgir em Fortaleza por volta da década de 80. Naquela época, as imagens que hoje são presença cotidiana nos muros da cidade, bem como em museus e galerias de arte, ainda eram raras, prevalecendo o chamado bomb, noção que designa o grafite produzido com letras largas e coloridas. Atualmente, há uma quantidade considerável de grupos que atuam na cidade e

9 Segundo membros do grupo Acidum, há quase uma "linha evolutiva" do desenho entre pichadores e grafiteiros, os quais guardam por vezes a marca deste percurso, acrescentando a assinatura pichada ao muro grafitado. Assim, representa uma exceção a passagem do grafite para a pichação.

10 O projeto chamava-se Crescer com arte e era promovido pela Fundação da Criança e da Família Cidadã (FUNCI), órgão da prefeitura de Fortaleza. 
seus modos de fazer se diversificaram, incluindo além do bomb, o desenho, as letras e os personagens ${ }^{11}$.

Em Fortaleza, foi criada em 2009, a Federação Cearense de Grafite. Embora o Grafiticidade não faça parte desta, seus membros reconhecem que a Federação é importante por promover encontros periódicos e manter a publicação de uma revista, a Rolê Graffiti $^{12}$. Ela tem o papel de reunir material sobre as variadas e, por vezes, concorrentes formas do grafite feito no Ceará, conferindo-lhes perenidade e visibilidade.

Exemplo da tensão que perpassa o "campo" do grafite local ${ }^{13}$ pode ser percebido no depoimento de um integrante do grupo Viciados em Tinta Spray (VTS), relacionando o grafite produzido por seu grupo e aquele do Grafiticidade. Este confronto expõe variações nos modos de fazer o autodesignado "grafite engajado" de Fortaleza, tornando a "orientação" assumida pelo coletivo Grafiticidade menos alinhada com esta referência.

Assim, de modo geral, há grupos cujo discurso vincula-se àquele de segmentos representados por movimentos sociais, ONGs e movimento Hip Hop - a exemplo do Grafiticidade - e outros coletivos, mais ligados às artes visuais, sendo alguns originados, inclusive, dos cursos de graduação em Artes, em Fortaleza. O coletivo Acidum é o exemplo mais flagrante desta segunda tendência.

A disputa pela legitimidade de cada uma dessas vertentes conduz à configuração de um jogo social, no qual por vezes a tática empregada é aquela da tentativa de desautorização do discurso e da prática do outro. Exemplo disso é dado pelo VTS: para um de seus integrantes, o que o Grafiticidade faz não deve ser considerado grafite, visto que este não representaria a "verdadeira cultura de periferia".

11 Estilo de grafite que se assemelha aos quadrinhos onde um personagem é criado.

12 A revista não foi comercializada, tendo sido distribuída apenas para os membros da Federação.

13 Em Fortaleza, a ideia de campo de tensões extrapola o universo do grafite, revestindo as relações entre grafiteiros e pichadores. As pichações feitas sobre os trabalhos grafitados em caixas telefônicas apontam a tensão que se estabelece por vezes entre uns e outros. 
Frente a esta afirmação, não cabe à perspectiva sociológica assumir uma posição normativa, distinguindo aquele que tem razão, daquele que não tem. De fato, nesta perspectiva, o que leva o integrante do VTS a fazer tal afirmação relaciona-se antes às disputas no campo do grafite e a um lugar de fala "autorizado", portanto, instrumentalizado para deslegitimar, do que à ausência de uma suposta essência que caracterizaria o grafite "legítimo" em Fortaleza.

De fato, a visibilidade que essa atividade vem adquirindo faz com que seus praticantes acumulem concepções e valores próprios para defini-la, buscando, no mesmo movimento, validar discursivamente suas posições. Assim, os grupos que estão mais próximos das artes plásticas são vistos, de modo recorrente, com desconfiança, como se desvirtuassem uma suposta "natureza" configurada pelo percurso histórico do grafite.

Frente a tais disputas, pensar relativamente a prática desses agentes, a partir de sua filiação a movimentos sociais, institucionalizados ou não, ou de sua ligação com as artes plásticas, ao contrário, pressupõe o distanciamento exigido pela pesquisa científica. Esta orienta o pesquisador a discernir hierarquias efêmeras, concretizadas por disposições diferenciadas, em boa medida inconscientemente, de grupos que se engajam seja na busca do reconhecimento público, pela convergência ou distinção em relação à pichação ${ }^{14}$, seja pela recorrência ou novidade de temas grafitados, ou ainda pelas técnicas utilizadas.

Diante do exposto, no período da gestão Fortaleza Bela, era possível apontar os grupos atuantes em Fortaleza, utilizando como critério a recorrência de seus grafites na cidade convertida em terreno de ação, de produção de novas formas de intervenção e de luta por um meio urbano portador de vitalidade. São eles: RAM (Revolução Através dos Muros); VTS (Viciados em Tinta Spray); P2K (Paridos pelo Kaos); Grafiticidade e Acidum.

14 "Certamente, a principal diferença entre as duas formas de intervenção urbana consiste em que a pichação advém da escrita enquanto o graffiti está diretamente relacionado com as artes plásticas, com a pintura e a gravura. A primeira privilegia a palavra e a letra ao passo que a segunda se relaciona com o desenho, com a representação plástica da imagem" (SOUZA, 2007, p. 18). 
A presença do grafite nas cidades brasileiras, e particularmente em Fortaleza, integra o escopo de uma cultura visual urbana, compreendendo as seguintes modalidades: pichações, stencils, stickers, lambe-lambe, xilogravura e outras modalidades de produção de imagens "artesanais". A caracterização de cada grupo a partir da forma/conteúdo que utiliza e do discurso com o qual se identifica publicamente compõe parte fundamental do esforço da pesquisa a ser realizada na apreensão da complexidade que marca este universo.

No entanto, é possível arriscar algumas considerações sobre os grupos acima citados, tendo como base o cruzamento de elaborações discursivas e visuais, coletadas via internet, bem como, por meio do contato direto, via trabalho de campo.

Segundo informações que constam em seu blog, o RAM é um grupo que foi criado em 2006, a partir da reunião de amigos, os quais acreditavam que o graffiti ${ }^{15}$ constitui uma ferramenta democrática para registrar idéias e protestos na superfície da cidade.

Sobre os efeitos de sua atuação, eles afirmam que "A cidade está ficando cada vez mais colorida porque esses jovens acreditam que suas idéias, alegrias e agonias também podem ser transmitidas com traços de spray em meio ao cenário urbano". O grupo critica aqueles grafiteiros que convertem sua prática em dinheiro ou fama, ao mesmo tempo em que afirma que esta "arte" deve ser desprendida e democrática:

É por isso que eles (os integrantes do RAM) estarão sempre na rua em primeiro lugar sem qualquer compromisso com o que podem usufruir do Graffiti, mas sim com o verdadeiro desejo de nunca parar de pintar. ${ }^{16}$

Em relação às técnicas, o RAM utiliza com freqüência látex e tinta spray. O grupo "passeia" por vários bairros e modos de fazer. A superfície na qual grafitam é previamente preparada com uma camada de tinta látex, o que confere maior durabilidade ao produto final. Sendo variados os temas grafitados, eles assumem invariavelmente um caráter de crítica e protesto.

15 Existem variações na grafia da palavra grafite.

16 Fonte: disponível em: <http://ramgraffiti.blogspot.com/2009/11/revolucaoatraves-dos-muros.html>. 
Por sua vez, o grupo VTS emergiu como uma das primeiras crews $^{17}$ em Fortaleza. As características formais e temáticas de seu trabalho assemelham-se àquelas do $R A M$ : defendem a ideia de que o grafite é, sobretudo, um instrumento de protesto, uma forma de intervir na realidade social para modificá-la; os materiais que utilizam também são o látex e a tinta spray; os temas e formas de realizar o grafite parecem com aqueles do $R A M$, porém a postura do grupo em relação aos diferentes usos desta atividade é supostamente mais "branda", como aponta o depoimento de um de seus integrantes.

Cara, eu acho que o graffiti em si já é um protesto, pois, já vai de afronto ao sistema. Acho que cada um faz sua idéia, quem quer seguir uma linha só de protesto, massa! Quem quer seguir uma linha só de letras, siga e assim vai o graffiti... É muito diverso e isso tem que ser respeitado. O importante é o respeito e nunca esquecer as origens em relação à pichação. Hoje, acho que isso diminuiu... essa comparação... São duas artes diferentes, porém próximas. (Tubarão, integrante do VTS). ${ }^{18}$

O P2K (Paridos Pelo Kaos) era então outro grupo atuante. Sua sigla é facilmente reconhecida nas intervenções presentes na cidade. As características de seu trabalho e processo criativo aproximam-se daquelas associadas aos grupos citados anteriormente. O P2K também "prepara" o muro antes, fazendo com que em um mesmo mural convivam diferentes estilos de grafite, desde personagens até bombs.

Por sua vez, o percurso do Grafiticidade, aludido no início do texto, conforma uma trajetória composta por intervenções, que se valem não apenas do grafite, mas também de outras atividades que utilizam a cultura visual urbana. Com frequência, o grupo ministra oficinas nas quais as técnicas da fotografia artesanal e do grafite são associadas, produzindo imagens híbridas. Outros materiais têm sido incorporados ao grafite desenvolvido por este

17 Categoria nativa que significa o nome dos grupos de grafiteiros, normalmente representado por siglas e reproduzido ao lado dos grafites feitos pelo grupo como se fosse sua assinatura.

18 Fonte: disponível em: <http://hgoce.blogspot.com/p/entrevistas.html>. 
grupo, a exemplo do jornal, apropriado na produção do desenho presente em alguns painéis.

A concepção de grafite manifestada por um dos integrantes do grupo expressa-se neste depoimento: "Acreditamos que o grafite é um jornal da rua, onde as informações são reais". Por isso, o panorama apresentado neste artigo pretende ser tão-somente um esforço analítico não exaustivo, a fim de evidenciar que o Grafiticidade, bem como o Acidum, de forma específica e exemplar, aliam recursos das artes plásticas à perspectiva crítica que vemos nos grupos P2K E VST.

\section{ACIDUM - O GRAFITE “BELO” E INSUBMISSO, ENTRE O MUSEU E A CIDADE}

Seria o grafite uma espécie de "artesania"? E que desdobramentos heurísticos poderiam ser apreendidos a partir da relação entre esta afirmação e o papel do grafite na elaboração de uma cultura visual da cidade? Sennett (2009) recupera a dignidade da atividade artesanal ao considerar que o trabalho feito pela mão mobiliza a mente e engaja-a em uma ação que tem por substrato a ideia do trabalho bem feito, ou de qualidade. Governando a si mesmo no permanente diálogo com técnicas, materiais e suportes, o "artesão" ou artífice é definido como todo aquele que cultiva o domínio de si por meio do desenvolvimento da chamada "mão inteligente".

E quem exercita o domínio de si pelo trabalho manual, imbuído da noção de qualidade, não reuniria melhores condições de contribuir para a gestão da coletividade? Não constituiria o grafite uma atividade artesanal ímpar de "apropriação dos espaços públicos por atores sociais urbanos", como preconiza Jacques (2004), por meio de uma prática não espetacular de envolvimento da comunidade citadina no processo de configuração permanente da paisagem urbana? Afinal, seria o grafite uma atividade que se enquadraria no âmbito das ações de revitalização do espaço urbano, fazendo-o pulsar por meio da mão que imprime linhas, formas e cores aos muros da cidade, ou deveria ser combatida por associar-se a práticas de poluição visual que desqualificariam a "beleza da cidade"? 
Partindo de tais questões, é preciso considerar que a arte tem constituído historicamente um domínio caracterizado pelo tratamento e produção de "coisas belas", havendo, nesse sentido, uma relação de continuidade com a chamada "arte urbana". Se, no mundo contemporâneo, a centralidade da reflexão sobre o belo na arte cedeu lugar à perspectiva que opõe o belo não mais ao feio, mas ao indiferente, as imagens produzidas pelo grafite provavelmente teriam dificuldades de se adequar totalmente com a primeira, mas certamente se encontrariam ao abrigo desta última concepção.

Assim, sob a lógica do impacto visual, fundamental à relação estética em espaços abertos como a rua, são continuamente geradas imagens que não são feitas para passarem despercebidas. Neste contexto, o grafite pretende configurar um cotidiano urbano desperto, arrancado à indiferença que se reproduz graças à inércia imposta pela repetição e excesso da experiência visual na cidade. É por meio de um olhar convocado a perceber as ruas de Fortaleza que seus habitantes descobrem-se incessantemente na presença da mão humana que configura imagens "tatuadas" sobre os muros da cidade.

Assim, se o investimento sobre a dimensão estética é evidente nos grupos Grafiticidade e Acidum ${ }^{19}$, certamente esta relação ganha contornos mais precisos na produção deste último, conferindo-lhe um status privilegiado de elaboração exemplar do que seria a beleza de Fortaleza, a partir da prática do grafite na cidade.

De fato, a trajetória de reconhecimento realizada pelo grupo insere-o também no cerne das dinâmicas que caracterizam a arte contemporânea em Fortaleza, mais especificamente no fluxo que se estabelece entre museu e cidade, e vice-versa. Tal fluxo tem sido marcado pela presença recorrente de dispositivos de registros, os quais conferem estabilidade às variadas formas que têm

$19 \mathrm{Na}$ capital cearense, no ano de 2008, aconteceram duas exposições de trabalhos destes grupos em lugares que são referência para a difusão cultural. O CCBN - o Centro Cultural Banco do Nordeste - abrigou a exposição de trabalhos do grupo Grafiticidade, cujo título foi "Grapheincidade". A outra exposição aconteceu no Museu de Arte Contemporânea do Centro Cultural Dragão do Mar (MAC/CDMAC). Esta teve como título "Entregue às moscas" e apresentou o trabalho do coletivo Acidum. 
assumido as chamadas intervenções urbanas (performances, instalações e outras).

Podemos destacar como característica da intervenção de arte urbana o uso dos espaços públicos da cidade e de monumentos, como meio de provocar a alteração de percepções em torno do cotidiano urbano e do papel da arte, cujo acesso indiscriminado de diversos segmentos de população, incita à reflexão. As intervenções são assim voltadas à criação de condições favoráveis para uma experiência estética capaz de produzir novas maneiras de perceber e de estabelecer relações afetivas com o espaço urbano que não apenas aquelas filiadas à objetividade do olhar funcional aplicado ao dia-a-dia.

É possível considerar um paralelo entre arte urbana, apropriada no espaço público, e a arte legitimada por instituições culturais, a exemplo dos museus. O sociólogo Pierre Bourdieu assim caracteriza a apropriação das obras realizadas a partir dos limites e possibilidades oferecidas por estas instituições.

A obra de arte deve, sem dúvida, boa parte de sua legitimidade ao fato de que a experiência que dela podem ter aqueles que estão desprovidos de saberes inúteis dos quais ela é solidária nada mais é do que o limite de uma experiência mais fundamental e mais ordinária: a do... "criador", que dá seu nome à obra "original" e "pessoal" e se atribui, assim, a propriedade e o operário sem qualificação, simples servidor de uma intenção que o ultrapassa, executor desapossado do pensamento de sua prática (BOURDIEU apud ORTIZ, 1983, p. 20-22).

Se os assim designados artistas de rua buscam formas de expressão de sua arte para além das curadorias dos museus, galerias ou quaisquer outros modos tradicionais de exposição é porque acreditam que essas instituições restringem as possibilidades da produção e recepção artísticas a uma determinada classe social.

Neste sentido, o desejo de ruptura com formas e espaços tradicionais das artes, acalentado pela arte moderna do início do século XX e concretizado pela emergência da abstração, ganhou força com a efemeridade das práticas geradas no seio da arte contemporânea. Tais práticas não tardaram a se insurgir contra o conjunto lógico que articulava a cadeia de produção artística representada pela instituição museológica. 
Assim, por sua busca de fluidez, tais formas de arte migraram do museu, esvaziando-o, e infiltraram-se no tecido urbano. Porém, a seguir, compondo um movimento inverso, elas têm sido chamadas a retornar ao espaço museológico. Desta feita, sob a forma de registros, tais obras viram-se atravessadas, em sua estrutura subversiva, por dispositivos técnicos de registro. Estes potencializaram o sentido de assepsia imposto por este meio a sua rebeldia, fragilizando-a.

Este duplo movimento pôs em xeque a concepção moderna de museu, concebido a partir de então de modo nostálgico como um campo semântico rarefeito, pleno de vazios, marcado antes pela noção de "trânsito" do que por aquela de "lugar".

Ocorre que o grafite, habitualmente associado à conversão da cidade em suporte para a veiculação de conteúdos imagéticos de caráter insurgente, ao ser convidado a fazer uso do espaço oferecido pelo museu, subverte-o, revitalizando-o. De fato, nesta perspectiva, o museu abandona sua condição de malha rarefeita para adquirir uma dupla densidade - aquela que concretiza a fusão entre museu e cidade, conformando a simultaneidade de dois lugares em um; e aquela que, a exemplo do ateliê de artista, preenche-o menos com fantasmagorias oferecidas por registros que celebram o poder absoluto das imagens do que com testemunhos de experiências artísticas concretizadas em atos.

Acrescente-se a tais questões o fato de que, se a produção visual do Acidum é de difícil classificação entre "seus pares", ela tem sido bem acolhida pelo domínio artístico. Deste modo, considerando os dados contidos no site do grupo, ele é descrito da seguinte forma:

O Acidum tem como linha geral de trabalho a adaptação de seu processo artístico aos ambientes escolhidos. Desenvolve um trabalho que explora, experimenta e se processa a partir do caos das paisagens e relações urbanas, choques e trânsitos culturais diversos. ${ }^{20}$

A citação acima evidencia a ligação que o grupo estabelece com o conjunto da cultura visual urbana local, assim como com o universo das artes plásticas, sendo o museu apenas um dentre os

20 Fonte: disponível em: <http://www.fotolog.com.br/junimroots/30667706> Acesso em: 20 dez. 2010. 
ambientes escolhidos para um trabalho que explora, experimenta e se processa em diálogo com as propriedades de diferentes lugares. Porém, não seria possível filiar facilmente este trabalho à produção de grafite em Fortaleza, se esta permanecesse restrita aos contornos estabelecidos por sua origem histórica - o desenho colorido por spray, impresso unicamente sobre os muros de uma cidade que é tomada como superfície/suporte de uma manifestação cuja finalidade última seria a contestação de valores e práticas sociais.

O grafite elaborado pelo Acidum se aproxima mais de um regime de produção visual alternativo àquele que pode ser chamado hoje de "grafite tradicional" - ele aponta uma fratura limite entre a prática deste e aquela desenvolvida pelas artes plásticas na contemporaneidade, cujo epicentro gira muita vezes em torno de questões ligadas à dimensão performática do corpo que, pelo traço, revela o gesto como extensão da atividade da mão e da mente do artista.

Mesmo quando, no campo artístico, a questão do "belo" ideal parece ter sido remetida ao passado, a beleza da e na cidade revela-se na aliança tácita ou explícita que se estabelece entre a insurgência do grafite e da arte contemporânea contra a mesmice no urbano. É, portanto, no trânsito entre estas duas esferas de produção visual que se processa a dupla revitalização - da cidade e do museu - como manifestações do caráter belo e insubmisso que caracteriza potencialmente a condição humana.

\section{O MAC “ENTREGUE ÀS MOSCAS"?}

Apesar da forte presença de cores, a visualidade produzida artesanalmente pelo grafite em Fortaleza traz como marca inconteste o trabalho plástico com o desenho. Neste contexto, a continuidade entre a desenvoltura da mão do "artista de rua" que traça o desenho de figuras e da escrita é semelhante àquela que facilita o trânsito entre "artistas de rua" que fazem a pichação, o grafite e a tatuagem.

Tais manifestações, segundo Tilburi e Chuí (2010), vinculam o traço do desenho ao avesso daquele expresso na cultura escolar letrada, pela estrutura lógica que este último assume como 
pensamento discursivo. Ele instrumentaliza e privilegia a abstração conceitual, em detrimento da inteligência configurada por processos associativo-visuais que provêm da prática manual do desenho e da pintura.

Por vezes, tal prática ganha contornos muito particulares entre os segmentos sociais que não vivenciam o sentimento de familiaridade com o universo da cultura letrada difundida pela escola. Frente a diversos tipos de opressão, seu desenho represado canaliza a rebeldia que transborda da frágil socialização escolar para as ruas.

Assim, na pichação o desenho territorializa, torna-se canal de divulgação clandestino de uma marca pessoal que se fixa pela repetição (SOUZA, 2007). Do mesmo modo, o sentido de marca pessoal se acha em jogo nas tatuagens que povoam as peles como um sinal de nascença escolhido (LEITÃO, 2004). Ou ainda, no desenho grafitado de modo tímido e experimental, feito para um dia ser descoberto em meio a ruínas, a exemplo do que fazia o grupo Acidum em 2007, no início de um percurso que se fez ao abrigo de uma assinatura coletiva.

Em seguida, o grupo assumiu abertamente a visibilidade da disputa por um lugar na paisagem urbana, instalando propositalmente tensões simbólicas entre o grafite e os materiais de propaganda e marketing que mesmo hoje preenchem outdoors ou os muros da cidade. Paralelamente, o Acidum obteve reconhecimento institucional por meio da premiação no Edital das Artes da Fundação de Cultura, Esporte e Turismo (FUNCET), órgão da Prefeitura que antecedeu a criação da SECULTFOR. Esta premiação subsidiou a pesquisa plástica que deu base à elaboração do portfólio apresentado à direção do Museu de Arte Contemporânea, compondo o material relativo à negociação da mostra "Entregue às Moscas", a qual teve lugar em 2008, exposto na imagem abaixo. 
Figura 2 - Pintura "Entregue às Moscas" na parede do Museu de Arte Contemporânea do Centro Cultural Dragão do Mar, 2008.

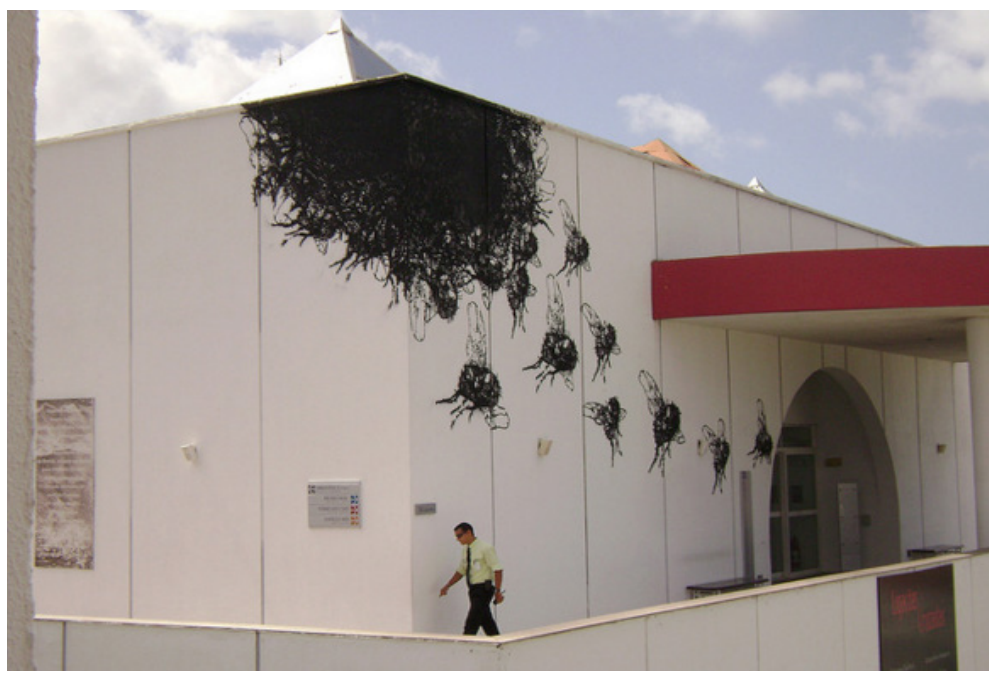

Fonte:disponívelem:<https://www.flickr.com/photos/acidum_expo/2346407625/>.

O título provocativo anunciava a invasão do MAC (simbolizada pelo enxame de moscas grafitadas nas paredes externas, entrando pela porta do Museu), bem como a inversão da lógica do cubo branco, colocado do avesso (o branco das paredes externas conspurcava-se, misturando-se ao burburinho da paisagem).

Para o Acidum, a ordem então era brincar/jogar com as regras institucionais do lugar; experimentar/elastecer os limites daquilo que era permitido às expressões da arte contemporânea; inverter/ desvirtuar as categorias fundamentais ao espaço museológico, convertendo a exposição em obra em andamento e o Museu em suporte; exercitar/incitar a "lógica do desapego" ligada à efemeridade do desenho grafitado, em oposição à estabilidade do produto artístico; conspurcar/adulterar a noção de autoria individual, dissolvendo-a no predomínio da assinatura coletiva ${ }^{21}$.

21 Em 2009, esta mesma lógica marcou a participação do Acidum no conjunto de exposições organizadas pela FUNARTE no Rio de Janeiro e em São Paulo, intitulada Da Rua: que arte é essa? 
Figura 3 - Mix Geral Sala Central/MAC

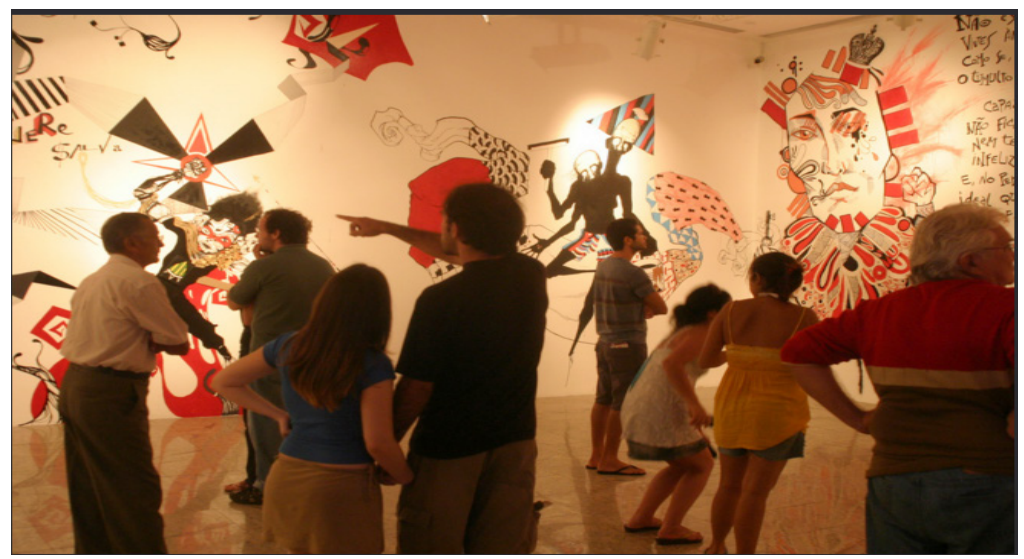

Fonte:disponívelem:<https://www.flickr.com/photos/acidum_expo/2681895478/>.

Explicitada por Robézio Marques, um dos integrantes do grupo Acidum, a questão da assinatura coletiva representa uma forma de reconhecimento de todos os artistas que estão no grupo em que afirma:

Era assim... A coisa da não autoria, né? Isso veio logo no começo quando cheguei pra galera e disse: 'ó, a gente vai assinar Acidum, durante um tempo vai ficar Acidum e é só isso. Não aparece nem o meu nome e nem o nome de ninguém'. Eu já tinha tido outras experiências com grupos. Sabia como era essa coisa do nome, de quem assina não sei o que... Então, é perigoso isso... A rivalidade que se tem hoje e vai sempre existir. Então, a gente tem que saber trabalhar isso. E eu pesquisei muito os grupos antigos, principalmente aqui em Fortaleza. Eles acabavam por isso. Assim, discussões por causa desse processo...

A aceitação de tal proposta levou-o à consagração na esfera artística, mas também convergiu com o reconhecimento do poder público, angariando junto à Municipalidade de Fortaleza uma sequência de premiações em editais da Secretaria de Cultura.

Neste contexto, a "ocupação" do MAC, equipamento ligado ao Centro Dragão do Mar de Arte e Cultura, colocou o Acidum no lugar que se constituiu em ícone do processo contemporâneo de espetacularização urbano em Fortaleza, pois, 
as estratégias de marketing urbano... buscam construir uma nova imagem para a cidade que lhe garanta um lugar na nova geopolítica das redes internacionais. As maiores vedetes são os grandes equipamentos culturais, franquias de museus e suas arquiteturas monumentais... que passam a ser as principais âncoras de megaprojetos urbanos (JACQUES, 2004, p. 27).

Assim, ao abrigar a disposição subversiva do "Entregue às Moscas", o MAC acabou sobrepondo à imagem da beleza espetacular do Centro Cultural àquela que figura criticamente "personagens" do processo de degradação de outro centro - o centro histórico e comercial de Fortaleza.

Figura 4 - Projeto Acidum

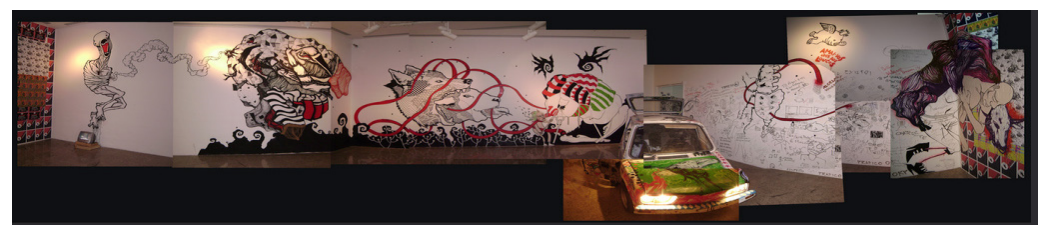

Fonte: disponível em: <https://www.flickr.com/photos/acidum_expo/ with/2718891593/>.

Segundo Robézio Marques, ao longo do processo de elaboração da exposição "Entregue às Moscas", no MAC, o museu era um limite alargado a partir de seu interior.

A gente conhece toda a estrutura, a gente sabe onde é que pode quebrar e onde a gente não pode no MAC. E depois que sua proposta é aceita, quando você tem essa chancela do artista que tá fazendo, que tá propondo o trabalho, é muito legal, porque aí a gente joga com essa coisa de até aonde vai a possiblidade da arte contemporânea. Aí, começou, "pô, não pode entrar água no museu, não pode entrar líquido, não pode entrar comida. Ah, e não pode ficar até tal horário.". Eu disse: "Cara, a nossa arte é efêmera, então vamos quebrar essa cláusula, e vamos botar isso como liberdade." Então, a gente começou a jogar, sabe?... E eles foram aceitando. Isso foi legal da parte do Guedes ${ }^{22}$. Ele deu toda liberdade, de horário, de tudo.

22 José Guedes, diretor do Museu de Arte Contemporânea do Centro Dragão do Mar de Arte e Cultura em 2009. 
O artista acrescenta que ao mesmo tempo em que a exposição Entregue às Moscas assinala o terceiro maior público do MAC, as imagens que revelam a memória desse projeto ferem a ideologia museológica moderna, maculando as paredes do cubo branco.

A gente ficou uma semana morando dentro do museu, recebendo amigos de madrugada. Só não podia deixar a porta da frente aberta e isso foi uma das coisas que a gente não conseguiu. Mas, se chegasse, podia entrar. Então assim, de madrugada teve galera que chegou, sei lá, quase dez pessoas lá dentro. Contando com a gente, até mais de dez pessoas. Um levava uma cervejinha, outro levava comida... Tem vídeos disso, guardados por causa da documentação da madrugada no museu. Então, a gente quebrou todas essas barreiras, e tudo isso fazia parte da obra da gente. Até a abertura da exposição tava (sic) incluída, porque era para usar as próprias paredes do museu e fazer aquela conexão com a expressão 'entregue às moscas'. A gente brincou com a noção de vernissage, de aglomerar, é tanto que, essa coisa da arte que às vezes se faz espetáculo, a gente usou muito a ideia de espetáculo da arte pop. A ideia era somar arte e entretenimento. Então, eu disse: "Se é isso que eles querem, vamo (sic) fazer isso de forma que a gente teja (sic) controlando." A gente fez e foi legal, porque ai rolou essa coisa do terceiro maior público do museu e tudo o mais.

Ao converter o MAC (ao longo do processo de criação da exposição) não só em ateliê, mas em alojamento de artistas, o Acidum emprestou ao Museu a mesma vitalidade que suas mãos conferiam de forma recorrente ao desenho grafitado nos muros da cidade.

\section{DEPOIS DO ACIDUM... O FESTIVAL CONCRETO DE ARTE URBANA}

Somente o acúmulo histórico e a inversão de valores sociais podem subsidiar a compreensão sociológica da emergência, desencadeada em parte pelo poder público, de um festival de arte urbana que servisse não apenas à celebração de "talentos" locais da arte urbana, mas o convite a nomes do grafite reconhecidos no Brasil e no exterior.

Quase quinze anos marcam a distância temporal que separa a consagração do grupo Acidum e a realização do Festival Concreto, em 2013, primeiro festival internacional de arte urbana realizada 
no Nordeste brasileiro. O evento pretendia integrar a cultura urbana de sete países das Américas e Europa, além de propiciar o encontro entre "artistas" internacionais, nacionais e locais.

Da longa lista ambicionada pelo estival, confirmaram presença: Mart (Argentina), Loomit (Alemanha), Borondo (Espanha), Gerson (México), Poeta (Argentina), Gris One (Colômbia), Galos (Pernambuco), Naldo (Maranhão), Italo Sponja (Paraíba) Cuco (Maranhão), Glauber Arbos (Pernambuco), Hudson Melo (Piauí), KefrenPok (Rio Grande do Norte), Alto Contraste (São Paulo), Rogério Arab (Pará) e 6emeia (São Paulo).

Assim constituído, o evento possibilitou a troca de saberes e experiências durante os dez dias de sua realização. Foram apresentadas gratuitamente exposições, intervenções, workshops, palestras, oficinas de técnicas e formas de expressão artística (a exemplo do muralismo, do grafite, da música e da dança), utilizando como suporte a cidade de Fortaleza, capital do Ceará.

O objetivo do Festival era transformar a cidade de Fortaleza em um museu a céu aberto, mostrando ao público não iniciado diferentes modalidades de intervenção artística, por meio de obras monumentais em diversos locais da cidade.

Assim, receberam murais em grande escala o bairro do Benfica, o Centro Dragão do Mar de Arte e Cultura, o Cuca da Barra do Ceará, o Farol do Mucuripe, a caixa d'água da Companhia de Água e Esgoto do Ceará - CAGECE, o cruzamento das avenidas Tibúrcio Cavalcante e Antônio Sales, a Casa de Cultura Francesa, e o Instituto Presídio Professor Olavo Oliveira - IPPOO.

A intervenção realizada no IPPOO assume a influência do movimento artístico muralista, presente na formação dos artistas. Estes, por meio da representação artística, convertem o muro do presídio, até então preenchido por extensa faixa monocromática ao longo da Avenida Expedicionários, em Fortaleza, uma via de acesso revitalizada sob o olhar das pessoas que passam e residem nas proximidades do local.

Segundo Narcélio Grud, idealizador do evento, não foi possível realizar todas as intervenções previstas. As caixas d'água da CAGECE deveriam ser todas pintadas, mas devido a uma limitação técnica - a falta de equipamentos para o alcance do topo dessa 
construção - muitas delas ficaram fora do conjunto de atividades materializadas.

Porém, é patente o alinhamento institucional do evento. As intervenções realizadas materializaram o propósito de mapear espaços que representassem todas as regionais de Fortaleza, em um diálogo próximo com a lógica de divisão administrativa feita pela Prefeitura de Fortaleza.

A partir deste critério, e por meio do olhar "treinado todo dia", Grud olhava muro a muro, tentando distinguir quais dentre eles tinham potencial para acolher as propostas de intervenções selecionadas. Os locais para esta atividade foram liberados com apoio da Prefeitura de Fortaleza e outros, por contato direto da organização do Festival.

A intervenção artística representada no muro do bairro Benfica, feita pelo grupo Alto Contraste, apresenta características estilísticas próprias, recorrentes no trabalho dos artistas. Suas composições são estruturadas a partir de cabeças de ursos e caricaturas de embalagens. Mesmo o fim do festival não provocou a retirada deste grafite. Cotidianamente ele ainda integra a paisagem pela qual passa um grande número de jovens universitários que estudam nas imediações e/ou residem no bairro.

\section{7 (IN)CONCLUSÃO}

A diversidade de expressões visuais urbanas, as quais têm o desenho por base e utilizam a cidade como suporte para suas práticas, é um campo desafiador para a reflexão elaborada no âmbito das Ciências Sociais. Este texto arrisca algumas reflexões sobre a arte urbana em Fortaleza, especialmente detendo-se particularmente na manifestação do grafite do grupo Acidum e na realização do Festival Concreto de Arte Urbana, em 2013.

O modelo interpretativo que afirma apressadamente a perda da autonomia criadora do grafite produzido pelo Acidum em função da suposta cooptação perversa sofrida por este, face à lógica institucional do museu e do poder público, obviamente não dá conta da complexidade deste fenômeno. 
A receptividade do Acidum no domínio artístico insere-se no contexto de um duplo movimento mundial de legitimação do grafite, revestido de aspectos relativos à consagração artístico/ patrimonial e à revitalização das cidades. Ao mesmo tempo em que o MAC consagra o grafite como forma artística, o tradicional modelo do cubo branco passa da condição esvaziada do museu "entregue às moscas" à de espaço revitalizado. Quanto ao poder público, o reconhecimento conferido por prêmios em editais ratifica não apenas a repercussão social do trabalho realizado por este grupo, mas também legitima a gestão Fortaleza Bela, confirmando sua feição supostamente jovem e democrática.

Deste modo, compondo uma cultura visual urbana por meio da atividade artesanal do desenho e da pintura, o grafite, bem como a pichação e a tatuagem, apesar de suas especificidades, intercambiam agentes e têm estabelecido trocas de mútua legitimação com o poder municipal.

Por ser portador de potência revitalizadora da beleza da cidade, o grafite concretiza o embate entre a identidade local e as tendências globais de espetacularização do espaço urbano. Reconfigurando a cidade segundo uma lógica alternativa de intervenção, o grupo Acidum chama assim para compor o espaço público segmentos da população periférica que representam o elemento não completamente controlável pela gestão municipal. Esta se vê confrontada com um modelo de administração urbana que exige a flexibilidade como elemento fundamental para lidar com a cultura e a arte como vias recorrentes de delineamento da Fortaleza Bela.

Assim, os modos de legitimação do grafite em Fortaleza parecem bem mais efetivos no campo artístico, do que na esfera da gestão pública. Neste contexto, os dispositivos criados pela administração municipal em Fortaleza parecem limitados no que tange à efetiva participação popular na elaboração da beleza da cidade.

A configuração simbólica e democrática de Fortaleza como "cidade bela", supunha a presença de agentes sociais que, a exemplo daqueles envolvidos com a prática do grafite, da pichação e da tatuagem, seriam considerados no diálogo público que redefine permanentemente a imagem urbana. Somente na gestão municipal posterior e da emergência do Festival Concreto de Arte Urbana 
foi possível observar a ampliação e concretização mais efetiva da plataforma política que buscava conjugar estetização da cidade e participação da população.

Frente a tais considerações, o sentido de (in)conclusão desse texto refere-se ao cruzamento de uma sociologia da arte e de uma sociologia urbana como um domínio interpretativo tão pouco canônico quanto seu objeto de pesquisa privilegiado neste momento. Assim, a arte de rua (representada neste momento pelo exercício manual que cria o grafite, mas também a pichação e a tatuagem), foi abordada como possibilidade de acesso à elaboração de uma noção alternativa de beleza da e na cidade, diversa daquela almejada pelos poderes públicos em sua versão patrimonial tradicional cujas ações de espetacularização do espaço urbano ficavam restritas à preservação da memória em sua forma edificada.

Alinhadas ao lançamento da segunda edição do Festival Concreto (2014) emergem assim pistas para uma reflexão sociológica que, desafiada por este novo contexto, talvez encontre um suporte analítico mais fecundo na aproximação entre o processo de legitimação simbólica e política pelo qual passa a prática do grafite e o campo do patrimônio imaterial. 


\section{REFERÊNCIAS}

BOURDIEU, P. O poder simbólico. Rio de Janeiro: Difel, 1989.

L'invention du paysage. Paris: Quadrige/Presses Universitaires de France (PUF), 2000. (Coleção Essais/Debats).

DIÓGENES, G. Cartografias da cultura e da violência-gangues, galeras e o movimento hip hop. São Paulo: Annablume, 1998.

FESTIVAL CONCRETO. Disponível em: <http://www. festivalconcreto.com.br/festival/>. Acesso em: jan. 2014.

GUERRERO, F.C. Graffiti, patrimonio eilegalidad. Disponível em: <https://www.academia.edu/4454514/Graffiti_patrimonio_e_ ilegalidad>. Acesso em: 15 jun. 2014.

JACQUES, P. B. Espetacularização urbana contemporânea. Cadernos PPG-AU/FAUFBA / Universidade Federal da Bahia. Faculdade de Arquitetura e Urbanismo, Salvador, ano 2, 2004.

LEITÃO, D. K. Mudanças de significado na tatuagem contemporânea. São Leopoldo: UNISINOS, 2004. (Cadernos IHU Idéias, ano 2).

ORTIZ, R. Pierre Bourdieu: Sociologia. São Paulo: Ática, 1983.

SENNETT, R. O artífice. Rio de Janeiro: Record, 2009.

SOUZA, D. da C. A. Pichação carioca: etnografia e uma proposta de entendimento. 2007. 12 f. Dissertação (Mestrado em Sociologia e Antropologia) - Programa de Pós Graduação em Sociologia e Antropologia, Instituto de Filosofia e Ciências Sociais, Universidade Federal do Rio de Janeiro, Rio de Janeiro, 2007. Disponível em: <http://www.comunidadesegura.org.br/files/pichacao\%20 carioca.pdf $>$.

TILBURI, M.; CHUÍ, F. Diálogo/desenho. São Paulo: Editora SENAC São Paulo, 2010. 